\title{
Indeks Pencemaran Muara Sungai Jodoh, Kota Batam
}

\author{
R. M. Rachmad Rizal Akbar, Winny Retna Melani, Tri Apriadi* \\ Program Studi Manajemen Sumberdaya Perairan, Fakultasllmu Kelautan dan Perikanan, Universitas Maritim Raja Ali Haji \\ J. Politeknik, Senggarang, Kota Tanjungpinang, Kepulauan Riau 29111 Indonesia \\ *Corresponding author, e-mail : tri.apriadi@umrah.ac.id
}

\begin{abstract}
ABSTRAK : Penentuan status mutu perairan perlu dilakukan sebagai acuan dalam melakukan pemantauan pencemaran kualitas air. Penelitian ini bertujuan untuk mengetahui tingkat pencemaran melalui nilai Indeks Pencemaran (IP) di perairan Muara Sungai Jodoh, Kota Batam. Lokasi pengambilan sampel berdasarkan metode purposive sampling di tujuh stasiun pada perairan Muara Sungai Jodoh Kelurahan Tanjung Uma Kota Batam. Parameter yang digunakan pada penelitian ini yaitu suhu, TSS, pH, DO, BOD, salinitas, dan bakteri coliform. Sebagai pembanding, digunakan baku mutu air laut untuk biota laut berdasarkan KEPMEN LH No.51 Tahun 2004. Perhitungan nilai IP dilakukan mengacu pada Keputusan Menteri Lingkungan Hidup Nomor 115 Tahun 2003 Tentang Penentuan Status Mutu Air. Berdasarkan hasil penelitian diketahui bahwa perairan muara Sungai Jodoh Kelurahan Tanjung Uma Kota Batam pada saat pasang maupun surut kualitas perairan tergolong tercemar ringan.
\end{abstract}

Kata Kunci : Baku Mutu; Indeks Pencemaran; Kualitas Air; Muara Sungai Jodoh

\section{Pollution Index of Jodoh River Estuary, Batam City}

ABSTRACT : The determination of water quality status needs to be done as a reference to monitor water pollution. This study aimed to determine the level of pollutions through the level of Index Pollution (IP) in Jodoh River estuary, Tanjung Uma, Batam City. The location of sampling based on purposive sampling method of seven station in the waters of Jodoh River, Tanjung Uma, Batam City. Physical chemichal parameters used in this study were temperature, TSS, $p H, D O, B O D$, salinity and coliform bacteria. The water quality results were compared with water quality standards based on KEPMEN LH No.51 2004 for marine biotas. IP calculation was reference to the Minister of Environment No.115 2003 concerning on determination of water quality status. Based on the results of this study showed the estuary waters in the Jodoh River, Tanjung Uma, Batam City, when at high and low tide the water quality were slightly polluted.

Keywords : Water Quality; Water Standard; Index Pollution; Jodoh River Estuary

\section{PENDAHULUAN}

Wilayah perairan teluk muara Sungai Jodoh termasuk dalam wilayah administrasi Pemerintah Kota Batam, Provinsi Kepulauan Riau. Pertumbuhan penduduk di Kota Batam tidak terlepas dari pengembangan kawasan Kota Batam sebagai kawasan industri, perdagangan, jalur lalu lintas kapal dan pariwisata. Badan Pusat Statistik (BPS) Kota Batam mencatat proyeksi pertumbuhan penduduk di Batam pada 2019 ini sebanyak 1.376.009 jiwa. Jumlah ini meningkat dibanding jumlah penduduk tahun 2018 sebesar 1.329.773, atau bertambah 234.193 jiwa dibandingkan jumlah penduduk lima tahun lalu. Imbas dari peningkatan penduduk Kota Batam juga memiliki dampak terutama pada lingkungan perairan. Kondisi ini tidak terlepas dari demografi Kota Batam yang juga merupakan kawasan pesisir. Menurut Jumali et al. (2017) pencemaran akibat limbah industri dan permukiman banyak terjadi pada ekosistem pesisir serta pada kondisi air laut.

Selain itu juga, kebutuhan lahan yang tinggi mengakibatkan adanya rekayasa teknologi berupa reklamasi lahan. Penambahan luas lahan melalui kegiatan reklamasi biasanya dilakukan di daerah pesisir dipilih sebagai solusi ruang atas kepadatan dan tingginya aktivitas perkotaan di 
daratan utama (mainland) (Peng et al. 2013). Reklamasi juga menyebabkan pemekaran kota menjadi intensif di pesisir sebagai imbas dari fenomena pertumbuhan penduduk yang tinggi, perkembangan ekonomi yang pesat, dan kontrol laut yang tidak memadai (Yurnita et al. 2017). Reklamasi laut memberikan kontribusi masalah lingkungan dan ekologi (Li, 2014). Berhadapan dengan perairan laut kelurahan tanjung uma didapati lokasi reklamasi pantai.

Muara Sungai Jodoh merupakan salah satu muara yang terdapat di Kota Batam. Berdasarkan informasi yang diperoleh dari penelitian Saprial et al. (2004) bahwa perairan Tanjung Uma merupakan muara sungai yang berasal dari kawasan Nagoya dan Jodoh yang telah berubah menjadi drainase induk kota. Wilayah Muara Sungai Jodoh banyak dimanfaatkan oleh masyarakat sebagai areal permukiman, jalur transportasi laut, objek wisata dan wisata kuliner serta reklamasi pantai. Banyakmya aktivitas yang ada didaerah muara Sungai Jodoh akan berpengaruh terhadap kondisi perairan yang ada di daerah tersebut, baik pengaruh fisika, kimia dan biologi perairan. Perairan Muara Sungai Jodoh merupakan salah satu faktor penunjang bagi kehidupan masyarakat sekitarnya. Banyak aktivitas masyarakat yang berlangsung di daerah tersebut berpotensi memberikan pengaruh langsung maupun tidak langsung.

Permasalahan yang sangat dominan bagi wilayah pesisir, pantai dan laut adalah terjadinya pencemaran yang mengakibatkan terjadinya penurunan kualitas dan kuantitas sumberdaya pesisir dan laut. Masukan limbah dari aliran drainase kota yang bermuara di kawasan muara Sungai Jodoh dan adanya kegiatan reklamasi pantai dikhawatirkan akan menjadi faktor utama yang mengakibatkan kerusakan ekosistem perairan. Kerusakan ekosistem perairan tersebut diawali dengan perubahan kondisi lingkungan perairan yang meliputi komponen fisik, kimiawi serta biologi perairan. Pencemaran perairan yang terjadi disekitar Kelurahan Tanjung Uma akan merubah kondisi fisik, kimiawi serta biologi perairan sehingga tidak layak (tidak sesuai baku mutu) bagi kehidupan biota maupun ekosistem yang ada disekitarnya.

Sejauh ini, belum dilakukan kajian terkini terkait dengan kondisi pencemaran perairan muara Sungai Jodoh Tanjung Uma untuk mengetahui level pencemaran yang telah terjadi pada saat ini. Sehingga dengan demikian, belum ada data yang valid terkait dengan kondisi pencemaran perairan sebagai dasar informasi dan pengelolaan kawasan perairan. Untuk itu, perlu dilakukan penelitian menganalisis dan mengkaji terkait dengan "Indeks Pencemaran Muara Sungai Jodoh Kelurahan Tanjung Uma, Kota Batam"

Berdasarkan Peraturan PP No.19 tahun 1999 tentang Pengendalian Pencemaran dan/atau Pengrusakan Laut adalah masuknya atau dimasukknnya makhluk hidup, zat, energi, dan/atau komponen lain ke dalam lingkungan laut oleh kegiatan manusia sehingga kualitasnya menurun sampai tingkat tertentu yang menyebabkan lingkungan laut tidak lagi sesuai dengan baku mutu dan/atau fungsinya. Perhitungan indeks pencemaran untuk biota laut didasarkan pada baku mutu menurut Kep. Men LH No.115 tahun 2003. Penelitian ini bertujuan untuk mengetahui tingkat pencemaran melalui nilai Indeks Pencemaran (IP) di perairan Muara Sungai Jodoh, Kota Batam. Hasil dari penelitian ini diharapkan dapat memberikan informasi dasar dan output yang dapat bermanfaat bagi pemerintah daerah maupun masyarakat umum, khususnya mengenai kualitas air laut sehingga dapat dijadikan sebagai masukan dan tolak ukur dalam perencanaan pengelolaan wilayah pesisir Kota Batam.

\section{MATERI DAN METODE}

Penelitian dilaksanakan di perairan Muara Sungai Jodoh, Kelurahan Tanjung, Uma Kota Batam pada Bulan maret 2019. Penentuan titik sampling ditentukan berdasarkan lokasi yang dekat dengan sumber kegiatan yang diduga memberikan beban pencemaran ke perairan tersebut. Sampel yang diambil mewakili kondisi lingkungan yang merupakan sumber masukan limbah ke dalam perairan dengan metode purposive sampling. Titik koordinat stasiun penelitian dan peta lokasi penelitian dapat dilihat pada Gambar 1. Pengukuran kualitas air laut secara insitu serta pemngambilan sampel air pada setiap stasiun dilakukan sebanyak 3 kali ulangan pada kondisi pasang serta surut. Sedangkan untuk pengambilan sampel air laut yang memerlukan analisis laboratorium dilakukan dengan memasukkan sampel air laut ke dalam botol sampel dan disimpan dalam coolbox untuk dianalisis. Parameter serta metode pengukuran dan standar analisis yang digunakan disajikan pada Tabel 1. 


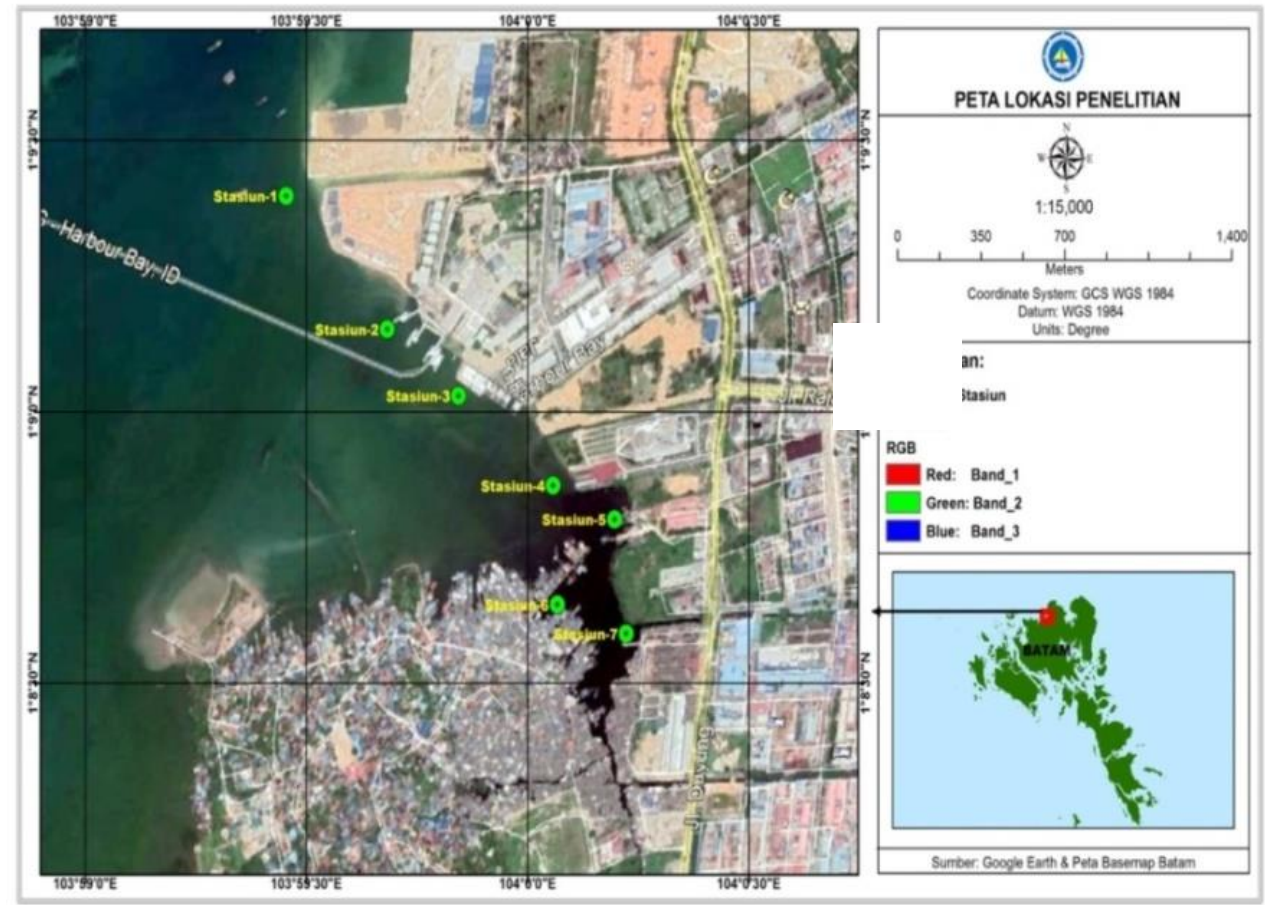

Gambar 1.Peta Lokasi Penelitian

Tabel 1. Parameter dan metode analisis kualitas air laut

\begin{tabular}{lcc}
\hline \multicolumn{1}{c}{ Parameter } & Tipe Analisis & Spesifikasi Alat / Metode Analisis \\
\hline Fisika & Insitu & Multitester \\
Suhu & Laboratorium & Gravimetri / SNI-06-6989.3:2004 \\
TSS & & \\
Kimia & Insitu & Multitester \\
pH & Insitu & Multitester \\
DO & Laboratorium & Inkubasi / SNI-6989.72:2009 \\
BOD & Insitu & Handrefraktometer \\
Salinitas & & \\
Biologi & Laboratorium & Membrane Filter \\
Total coliform & & \\
\hline
\end{tabular}

Dari hasil pengukuran parameter di lapangan dan hasil uji laboratorium di setiap lokasi titik sampling dibandingkan dengan kategori baku mutu sesuai dengan Keputusan Menteri Lingkungan Hidup No.51 tahun 2004 tentang baku mutu air laut untuk biota laut. Selanjutnya dilakukan perhitungan nilai indeks pencemaran sesuai dengan Keputusan Menteri Lingkungan Hidup No.115 tahun 2003 tentang Status Mutu Air sebagai pembanding dengan baku untuk mengetahui tingkat pencemaran di lokasi titik sampling tersebut. Dengan rumus IP :

$$
P I_{j}=\sqrt{\frac{\left(C_{i} / L_{i j}\right) 2_{M}+\left(C_{i} / L_{i j}\right) 2_{R}}{2}}
$$

Keterangan : $\mathrm{Pl}_{\mathrm{j}}=\mathrm{H}$ Indeks Pencemaran bagi peruntukan (j) yang merupakan fungsi dari Ci/Lij; $(\mathrm{Ci} / \mathrm{Lij})_{M}=$ Nilai maksimum dari $\mathrm{Ci} / \mathrm{Lij} ;\left(\mathrm{C}_{\mathrm{i}} / \mathrm{L}_{\mathrm{ij}}\right)_{\mathrm{R}}=$ Nilai rata-rata $\mathrm{C}_{\mathrm{i}} / \mathrm{L}_{\mathrm{ij}} ; \mathrm{L}_{\mathrm{ij}}=$ Menyatakan konsentrasi parameter kualitas air yang dicantumkan dalam Baku Peruntukan Air $\left({ }_{\mathrm{j}}\right) ; \mathrm{C}_{\mathrm{i}}=$ konsentrasi parameter kualitas air (i) yang diperoleh dari hasil analisis cuplikan air pada suatu lokasi pengambilan cuplikan air pada suatu lokasi pengambilan cuplikan air pada suatu wilayah laut. 


\section{HASIL DAN PEMBAHASAN}

Perairan Muara Sungai Jodoh terletak di Tanjung Uma Kecamatan Lubuk Baja Kota Batam. Di sekitar perairan ini terdapat aktivitas reklamasi, restoran, hotel, pelabuhan kapal ferry dan pelabuhan bongkar muat, pemukiman penduduk, serta perairan teluk yang merupakan muara dari drainase induk Sungai Jodoh Kota Batam. Dengan banyaknya aktivitas di sekitar wilayah perairan muara Sungai Jodoh tidak dapat dipungkiri akan adanya limbah yang dihasilkan. Hasil pengukuran kualitas air laut pada perairan Muara Sungai Jodoh Kelurahan Tanjung Uma Kota Batam baik secara fisika, kimia, dan biologi pada saat pasang dan surut dapat dilihat pada Tabel 2.

Nilai rata-rata parameter fisika dan kimia yang terukur selama tiga kali pengamatan secara umum menunjukkan hasil yang mendukung bagi kehidupan biota laut, meskipun ada beberapa parameter yang tidak memenuhi baku mutu yang ditetapkan berdasarkan Keputusan Menteri Lingkungan Hidup No.51 Tahun 2004.

Fluktuasi suhu yang ada di perairan Muara Sungai Jodoh dipengaruhi oleh kondisi cuaca pada saat pengambilan data. Pengambilan data suhu surut dilakukan pada siang hari, sedangkan suhu pasang dilakukan pada sore hari. Hasil pengukuran suhu disajikan pada Gambar 2.

Berdasarkan Gambar 3 diketahui bahwa pada saat pasang suhu perairan di setiap stasiun relatif stabil, yaitu berkisar $29,5-30,2^{\circ} \mathrm{C}$. Sedangkan pada saat surut, suhu tertinggi ditemui pada stasiun 4 dan stasiun 7 dengan nilai suhu $32,8^{\circ} \mathrm{C}$. Tingginya nilai suhu pada stasiun 4 dapat disebabkan masukan dari sisa aktivitas hotel yang langsung dibuang ke laut, sedangkan stasiun 7 merupakan muara dari drainase induk kawasan Nagoya dan Jodoh yang banyak membawa banyak material hasil sisa aktivitas kota. Tingginya nilai suhu saat surut pada seluruh stasiun juga dapat disebabkan oleh volume air yang berkurang pada saat surut sehingga paparan sinar matahari lebih cepat memengaruhi kondisi suhu perairan. Sedangkan pada saat air pasang, volume air lebih tinggi sehingga pengaruh paparan sinar matahari akan lebih lama memengaruhi perubahan suhu perairan.

Tabel 2. Hasil pengamatan Kualitas Air Laut Muara Sungai Jodoh pada saat pasang (abu-abu) dan saat surut (putih)

\begin{tabular}{|c|c|c|c|c|c|c|c|c|c|c|}
\hline No & Parameter & Satuan & $\begin{array}{l}\text { Baku } \\
\text { Mutu }\end{array}$ & ST 1 & ST 2 & ST 3 & ST 4 & ST 5 & ST 6 & ST 7 \\
\hline \multicolumn{11}{|l|}{ Fisika } \\
\hline \multirow[t]{2}{*}{1} & Suhu & ${ }^{\circ} \mathrm{C}$ & $28-32$ & 30,1 & 30,2 & 30,2 & 30,0 & 29,8 & 29,5 & 29,8 \\
\hline & & & & 31,2 & 31,1 & 31,6 & 32,8 & 32,2 & 32,4 & 32,8 \\
\hline \multirow[t]{2}{*}{2} & TSS & $\mathrm{mg} / \mathrm{L}$ & 20 & 24,3 & 25,7 & 18,3 & 16,3 & 8,3 & 7,0 & 13,3 \\
\hline & & & & 25,3 & 26,0 & 19,7 & 19,3 & 24,0 & 21,3 & 11,3 \\
\hline \multicolumn{11}{|l|}{ Kimia } \\
\hline \multirow[t]{2}{*}{3} & $\mathrm{pH}$ & - & $7-8,5$ & 7,8 & 7,9 & 8,0 & 8,3 & 8,1 & 8,2 & 8,9 \\
\hline & & & & 7,8 & 8,5 & 8,9 & 8,8 & 8,7 & 8,8 & 8,9 \\
\hline \multirow[t]{2}{*}{4} & DO & $\mathrm{mg} / \mathrm{L}$ & $>5$ & 7,1 & 7,1 & 6,6 & 6,6 & 6,5 & 6,5 & 5,9 \\
\hline & & & & 7,1 & 6,8 & 6,7 & 6,6 & 6,5 & 6,5 & 5,8 \\
\hline \multirow[t]{2}{*}{5} & Salinitas & $\%$ & - & 32,7 & 32,7 & 33,0 & 32,3 & 33,0 & 32,3 & 18,7 \\
\hline & & & & 27,7 & 21,3 & 25,0 & 22,3 & 10,0 & 8,0 & 6,3 \\
\hline \multirow[t]{2}{*}{6} & BOD & $\mathrm{mg} / \mathrm{L}$ & 20 & 3,2 & 3,1 & 2,7 & 3,7 & 4,5 & 4,5 & 5,4 \\
\hline & & & & 3,4 & 3,5 & 4,9 & 6,1 & 5,9 & 5,9 & 5,2 \\
\hline \multicolumn{11}{|l|}{ Biologi } \\
\hline \multirow[t]{2}{*}{7} & Coliform & MPN/100 & 1000 & 14 & 21 & 38 & 19 & 11 & 11 & 21 \\
\hline & & $\mathrm{mL}$ & & 54 & 50 & 82 & 82 & 59 & 74 & 61 \\
\hline
\end{tabular}

Mengacu pada penelitian yang dilakukan oleh Supenah et al. (2015) pada kawasan Sungai Condong yang berdekatan dengan permukiman dan industri, sehingga memperoleh nilai suhu sekitar $30-33^{\circ} \mathrm{C}$, dari hasil penelitian tersebut suhu akan meningkat sejalan dengan peningkatan aktivitas permukiman 
yang berada di sekitarnya. Berdasarkan Keputusan Menteri Lingkungan Hidup Nomor 51 Tahun 2004 bahwa kondisi suhu yang sesuai dengan kehidupan biota akuatik antara 28 - $30 \stackrel{\circ}{\circ}$. Mengacu dari sumber tersebut, suhu di perairan Tanjung Uma masih memenuhi kriteria baku mutu disaat pasang, namun sebaliknya disaaat surut tidak sesuai kriteria baku mutu.

Total Suspended Solid atau Total Padatan Tersuspensi (TSS) merupakan parameter yang menggambarkan besaran partikel yang mengalami pengendapan ke dasar perairan. Menurut Fransisca (2011) zat padat tersuspensi merupakan indikator pencemaran perairan pesisir yang bersumber dari pemanfaatan ruang perairan. TSS berasal dari kegiatan permukiman, industri dan sebagainya dipengaruhi oleh adanya proses-proses yang berasal dari dinamika pantai termasuk arus dan gelombang memengaruhi tingginya materi pencemar berupa zat padat tersuspensi. Hasil pengukuran TSS disajikan pada Gambar 3.

Berdasarkan Gambar 2 dapat dilihat bahwa konsentrasi parameter TSS yang melebihi baku mutu yaitu pada stasiun 1 dan stasiun 2 baik dalam keadaan pasang maupun surut serta pada stasiun 5 dan 6 pada saat surut. Nilai rata-rata parameter TSS pada kedua stasiun tersebut berada diatas ambang batas maksimal yang diperbolehkan dalam Keputusan Menteri Lingkungan Hidup Nomor 51 Tahun 2004 bahwa nilai TSS yang memenuhi syarat untuk kehidupan biota akuatik ialah <20 mg/L, sebab dalam kondisi tersebut menyebabkan kondisi yang kurang baik bagi biota laut.

Tingginya nilai TSS pada stasiun 1 dan stasiun 2 dapat disebabkan oleh terbawanya material pasir dan limbah hasil sisa reklamasi ke badan perairan dan juga pergerakan kapal yang menghasilkan ombak juga dapat mengikis bagian pantai yang direklamasi. Hal ini sesuai dengan pendapat Nurfatimah et al. (2019) yang menyatakan bahwa aktivitas pengerukan dan reklamasi di wilayah pesisir juga dapat menjadi penyumbang tingginya konsentrasi nilai TSS di perairan.

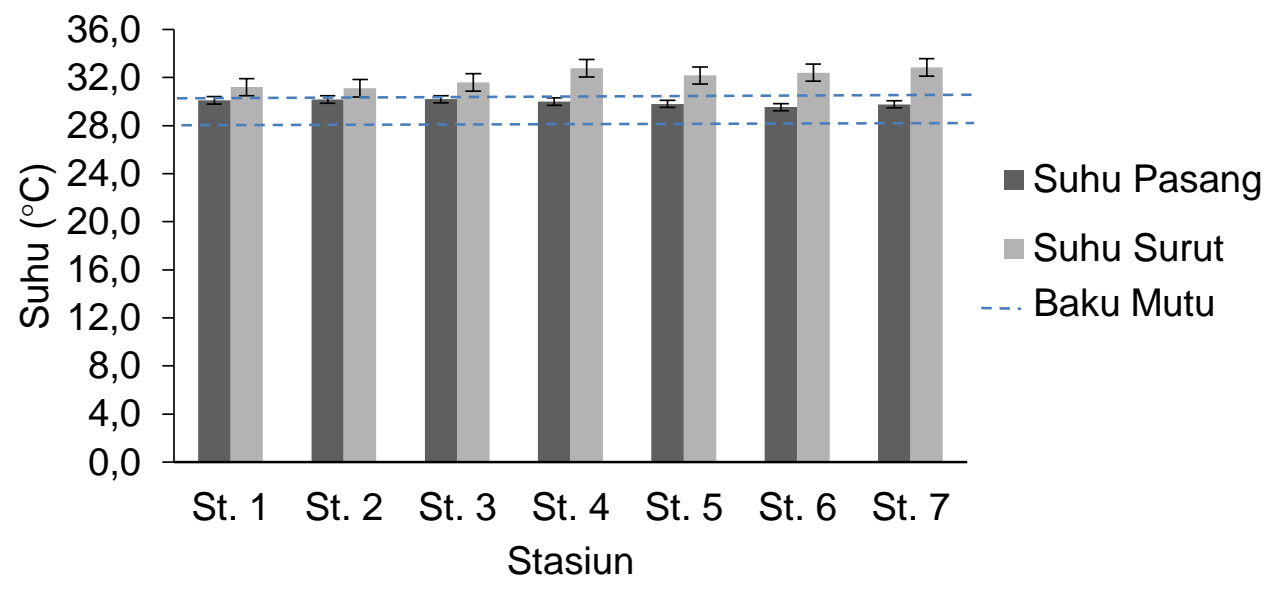

Gambar 2. Nilai rata-rata suhu di perairan Muara Sungai Jodoh, Kota Batam

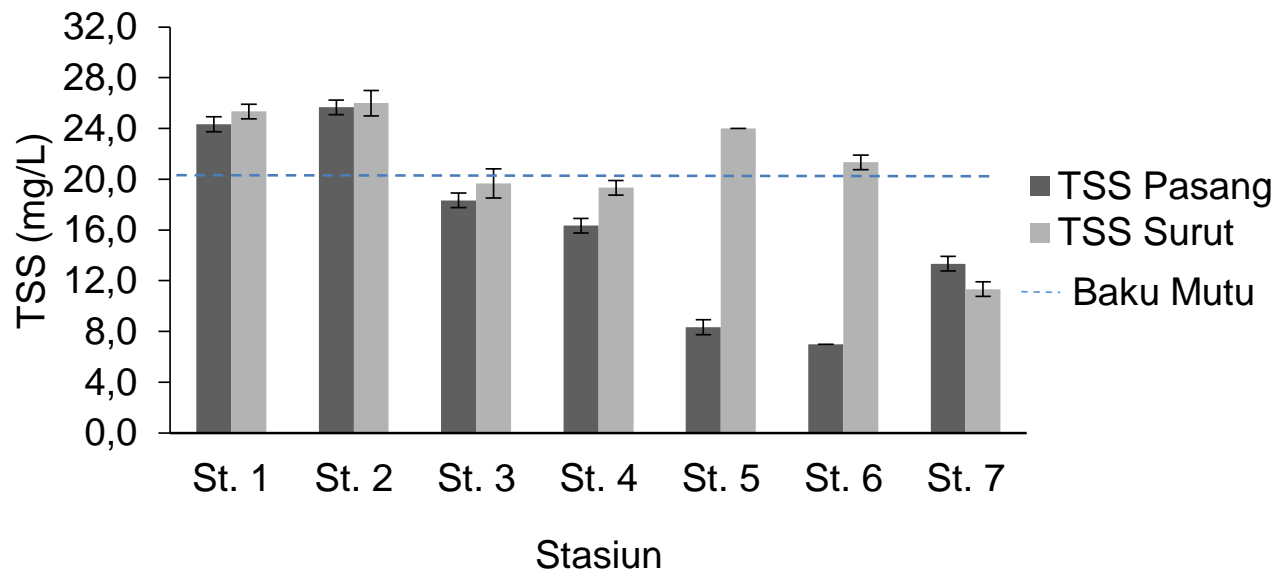

Gambar 3. Nilai rata-rata TSS di perairan Muara Sungai Jodoh, Kota Batam 
Sedangkan pada stasiun 5 dan 6 nilai TSS yang didapat pada saat surut lebih tinggi dibandingkan pada saat pasang. Hal ini disebabkan pada saat surut perairan menjadi sempit serta sedimen lumpur yang mengendap. Selain itu juga kondisi ini disebabkan karena adanya aktivitas domestik seperti pemukiman yang berada di atas perairan (pelantar), pasar dan pelabuhan bongkar barang. Aktivitas tersebut menghasilkan limbah buangan baik organik maupun anorganik, seperti sisasisa makanan, air buangan (mandi, cuci, kakus) serta tumpahan minyak dari kapal-kapal nelayan yang langsung masuk keperairan.

Mengacu kepada penelitian yang dilakukan dilakukan di perairan laut Kelurahan Belian Batam, Kota Batam didapati nilai TSS pada saat pasang maupun saat surut tidak sesuai baku mutu. Menurut hasil penelitian tersebut, tingginya nilai TSS di lokasi tersebut disebabkan oleh wilayah perairan yang merupakan kawasan pasca reklamasi daratan sehingga menjadi salah satu penyebab suplai air yang berasal dari daratan masuk ke perairan laut yang membawa material sedimen tersuspensi, dan apabila hujan air dari daratan mengalir diatas permukaan tanah mengalir menuju perairan (run off).

Menurut Salmin (2005) peranan oksigen terlarut sangat penting untuk membantu mengurangi beban pencemaran pada perairan secara alami maupun secara perlakuan aerobik yang ditujukan untuk memurnikan air buangan industri dan rumah tangga. Hasil pengukuran oksigen terlarut disajikan pada Gambar 4.

Nilai rata-rata oksigen terlarut di perairan Muara Sungai Jodoh pada saat pasang maupun surut masih memenuhi baku mutu, berdasarkan pada Keputusan Menteri Lingkungan Hidup Nomor 51 Tahun 2004 bahwa nilai oksigen terlarut yang sesuai untuk kehidupan biota akuatik yakni $>5 \mathrm{mg} / \mathrm{L}$. Nilai rata-rata DO paling tinggi terdapat pada stasiun 1 dan stasiun 2 dengan konsentrasi DO sebesar $7,1 \mathrm{mg} / \mathrm{L}$. Meskipun nilai TSS pada kedua stasiun ini melebihi ambang baku mutu akan tapi nilai DO yang didapat masih sesuai dengan baku mutu. Hal ini disebabkan pada wilayah tersebut merupakan perairan terbuka, sehingga memungkinkan adanya hasil fotosintesis organisme selain itu juga wilayah ini berdekatan dengan pelabuhan ferry, pergerakan kapal menyebabkan gangguan pada permukaan perairan sehingga menyebabkan difusi oksigen dari udara masuk ke perairan. Hal ini dibenarkan oleh Salmin (2005) yang menyatakan bahwa sumber utama oksigen dalam suatu perairan berasal dari hasil fotosintesis organisme yang hidup dalam perairan tersebut, selain dari proses difusi dari udara bebas.

Sedangkan konsentrasi oksigen terlarut terendah terdapat pada stasiun 7 dengan nilai $5,8 \mathrm{mg} / \mathrm{L}$ dan 5,9 mg/L saat pasang dan surut. Hal ini dapat disebabkan oleh pengaruh dari adanya aktivitas permukiman yang menghasilkan buangan organik berupa sisa-sisa makanan menyebabkan nilai DO menjadi rendah. Hal ini dapat terjadi karena oksigen tersebut digunakan oleh bakteri untuk mengurai bahan organik. Kondisi ini dibuktikan dengan pengukuran nilai BOD yang tertinggi pada stasiun 7 dengan rata-rata sebesar $5,3 \mathrm{mg} / \mathrm{L}$. Hal ini menggambarkan bahwa pencemaran bahan organik di stasiun 7 lebih tinggi dibandingkan stasiun lainnya.

Derajat keasaman merupakan parameter kimia yang menggambarkan derajat asam suatu perairan. Tiap organisme akuatik memiliki batas toleransi terhadap variasi nilai $\mathrm{pH}$ di perairan (Simanjuntak, 2012). Hasil pengukuran pH perairan Muara Sungai Jodoh disajikan pada Gambar 5.

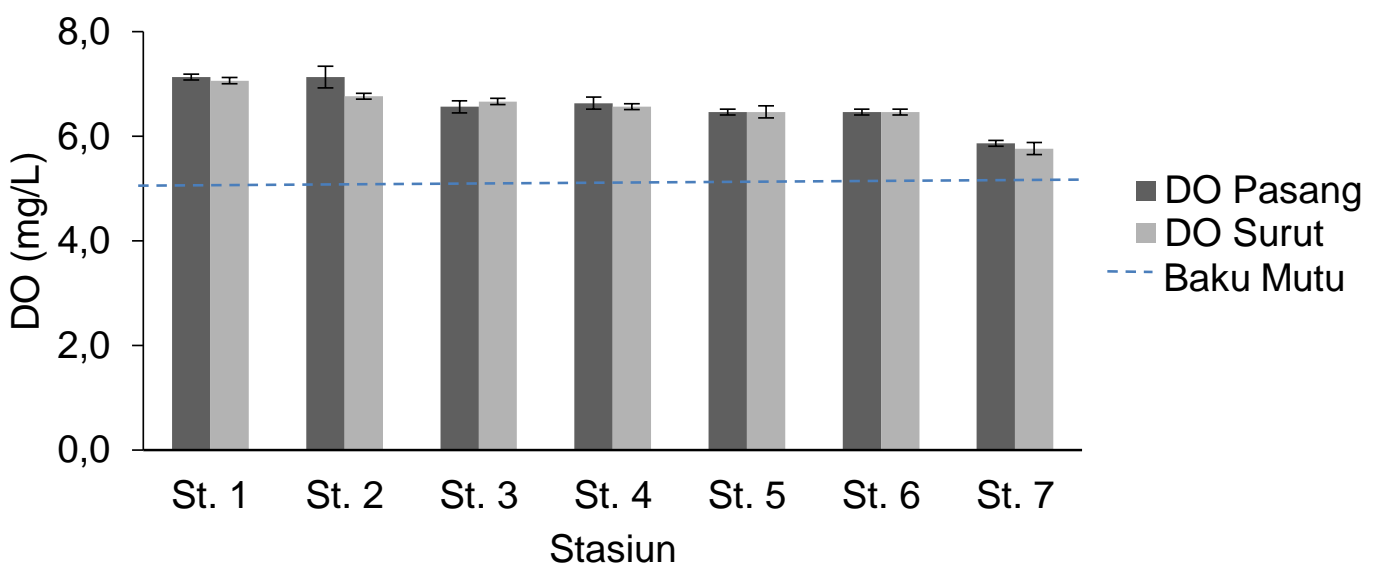

Gambar 4. Nilai rata-rata DO di perairan Muara Sungai Jodoh, Kota Batam 


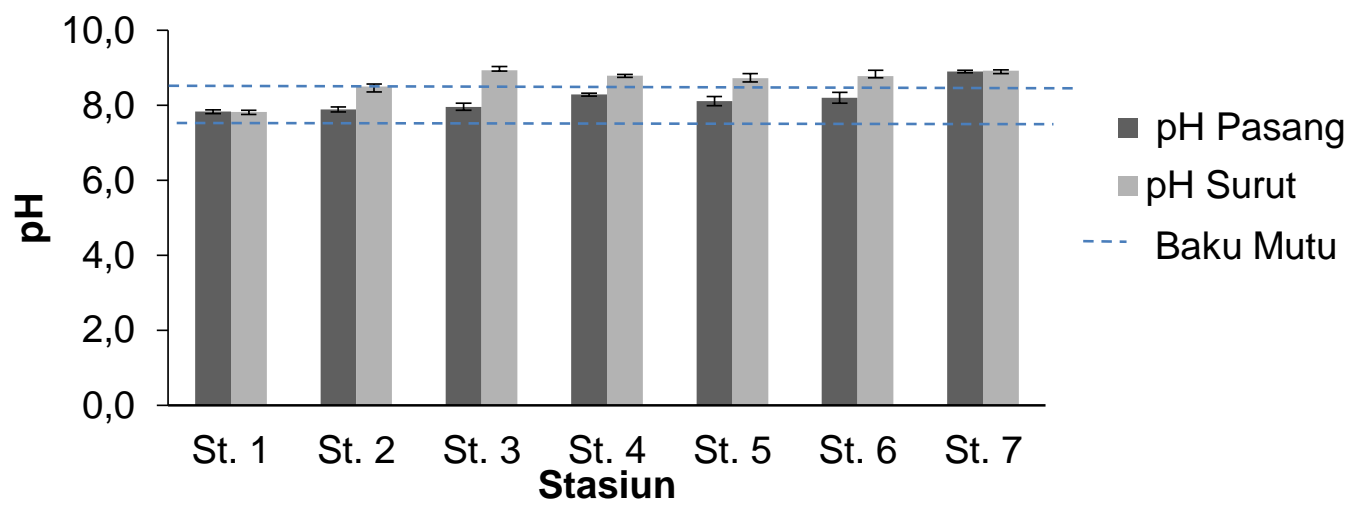

Gambar 5. Nilai rata-rata $\mathrm{pH}$ di perairan Muara Sungai Jodoh, Kota Batam

Nilai konsentrasi pH tertinggi dan melebihi ambang baku mutu pada saat pasang didapati pada stasiun 7 dengan nilai $\mathrm{pH} 8,9$. Hal tersebut dapat disebabkan oleh limbah domestik dari perkotaan yang mengalir melalui drainase induk sungai jodoh yang bermuara pada stasiun ini. Nilai pH lebih dari 8,5 artinya perairan bersifat basa. Sedangkan pada saat surut berturut-turut mulai dari stasiun 7 menuju stasiun 3 mulai dari muara Sungai Jodoh mengarah ke perairan terbuka didapati nilai $\mathrm{pH}$ berfluktuasi berkisar antara 8,7 - 8,9 tentunya nilai tersebut berada di atas baku mutu menurut pada Keputusan Menteri Lingkungan Hidup Nomor 51 Tahun 2004 bahwa kisaran pH yang sesuai untuk kehidupan biota akuatik yakni antara $7-8,5$. Hal ini dapat disebabkan oleh masukan dari berbagai aktivitas restoran, hotel, pelabuhan bongkar muat, pemukiman penduduk, dan buangan dari perkotaan.

Menurut Ali et al. (2013) peningkatan nilai pH perairan dikarenakan adanya aktivitas pembuangan limbah organik yang bersumber dari limbah domestik maupun limbah yang berasal dari aktivitas di sekitar yang masuk ke perairan. Namun kondisi tersebut berbenturan dengan pernyataan Triyulianti et al. (2012) yang mengatakan jika dengan adanya pengaruh masukan sungai yang membawa material organik dan anorganik akan menurunkan nilai salinitas (adanya masukan air tawar) maka kondisi $\mathrm{pH}$ juga akan berubah dengan cenderung menurun konsentrasinya. Makin besar kosentrasi BOD suatu perairan, menunjukan konsentrasi bahan organik di dalam air juga tinggi (Yudo, 2010). Hasil pengukuran parameter BOD dapat dilihat pada Gambar 6.

Nilai rata-rata konsentrasi BOD tertinggi pada saat pasang didapati pada stasiun 7 dengan nilai $5,4 \mathrm{mg} / \mathrm{L}$. Tingginya nilai BOD pada stasiun tersebut diduga disebabkan oleh proses penguraian mikroorganisme yang memerlukan oksigen, mengingat stasiun 7 berdekatan dengan drainase induk kota yang membawa limbah domestik dari pusat perdagangan dan pemukiman Nagoya dan Jodoh. Seperti pernyataan Supenah et al. (2015) yang menyatakan bahwa kadar BOD yang tinggi disebabkan karena adanya aktivitas pembuangan limbah domestik rumah tangga, limbah pasar dan pertanian menyebabkan meningkatnya bahan organik dalam perairan.

Sedangkan pada saat surut, konsentrasi BOD meningkat pada stasiun 3, 4, 5, dan 6 sebesar 5,9 $\mathrm{mg} / \mathrm{L}-6,1 \mathrm{mg} / \mathrm{L}$ dengan perbedaan yang cukup signifikan jika dibandingkan dengan nilai BOD pada saat pasang. Hal ini dapat disebabkan proses dekomposisi mikroorganisme pada saat surut lebih tinggi dari pada saat pasang. Mengingat lokasi stasiun yang berdekatan dengan restoran dan pemukiman penduduk diduga menerima masukan limbah organik yang cukup tinggi. Berdasarkan kriteria tingkat pencemaran dari nilai BOD, maka pada stasiun tersebut tergolong pencemaran rendah. Semakin tinggi konsentrasi BOD yang tingkat pencemarannya masih rendah dapat dikategorikan sebagai perairan yang baik. Menurut Salmin (2005) menyatakan bahwa tingkat pencemaran rendah jika nilai BOD $0-10 \mathrm{mg} / \mathrm{L}$, sedangkan tingkat pencemaran sedang jika nilai BOD $10-20 \mathrm{mg} / \mathrm{L}$.

Nilai BOD yang diperoleh pada seluruh stasiun masih sesuai standar maksimum BOD yang dianjurkan untuk biota laut dalam Keputusan Menteri Lingkungan Hidup No. 51 tahun 2004 untuk kehidupan biota laut dengan nilai maksimal $20 \mathrm{mg} / \mathrm{L}$. Rendahnya nilai parameter BOD dilokasi pengamatan dapat disebabkan karena terjadinya pencemaran biologi di kawasan perairan tersebut 
masih rendah. Dari nilai tersebut dapat kita ketahui bahwa kemampuan perairan dalam mendegradasi bahan organik masih cukup baik. Kemampuan memulihkan diri (self purification) yang dimiliki oleh periran pada lokasi sampling masih tinggi.

Akan tetapi, rendahnya nilai BOD pada suatu perairan belum tentu dapat dikatakan bebas dari bahan pencemar, apabila parameter kunci lainnya tidak diketahui. Apabila parameter kunci lainnya memiliki nilai yang melebihi ambang batas baku mutu, maka dapat diindikasikan terjadi juga pencemaran di perairan wilayah tersebut. Secara keseluruhan nilai BOD di perairanTanjung Uma masih memenuhi baku mutu. Meskipun terdapat perbedaan nilai BOD pada stasiun dengan aktivitas permukiman dan perairan terbuka, akan tetapi secara keseluruhan kondisi BOD masih sesuai dengan baku mutu. Menurut Supenah et al. (2015) bahwa kadar BOD yang tinggi disebabkan karena adanya aktivitas pembuangan limbah domestik rumah tangga, limbah pasar dan pertanian menyebabkan meningkatnya bahan organik dalam perairan. Salinitas merupakan parameter yang diukur untuk mengetahui konsentrasi garam terlarut dalam air laut. Salinitas dapat lebih rendah jika terdapat pencampuran air tawar ke air laut dan lebih tinggi jika air laut lebih dominan menempati suatu perairan. Hasil pengukuran parameter salinitas dapat dilihat pada Gambar 7.

Berdasarkan hasil pengukuran nilai rata-rata pada saat pasang masih memenuhi baku mutu, mengacu pada Keputusan Menteri Lingkungan Hidup Nomor 51 Tahun 2004 bahwa kisaran salinitas yang sesuai untuk kehidupan biota akuatik yakni antara 33 - $34 \%$. Akan tetapi pada stasiun 7 didapati nilai salinitas menurun secara signifikan dari stasiun sebelumnya yaitu 18,7\%o. Hal ini disebabkan oleh masukan air tawar dari drainase induk kota yang bermuara di wilayah tersebut. Menurut Effendi (2003) menyatakan bahwa nilai salinitas kurang dari $30 \%$, nilai tersebut berada pada kisaran $0,5 \%$ - $30 \%$ o yang berarti salinitas perairan tersebut payau (Effendi, 2003).

Sesuai pernyataan sebelumnya, nilai salinitas pada saat surut, mulai dari stasiun 1 yang berhadapan dengan laut terbuka distribusi salinitas cenderung menurun menuju peairan teluk yang berada dekat dengan stasiun 7 yaitu muara Sungai Jodoh. Suplai air tawar yang sangat besar dari

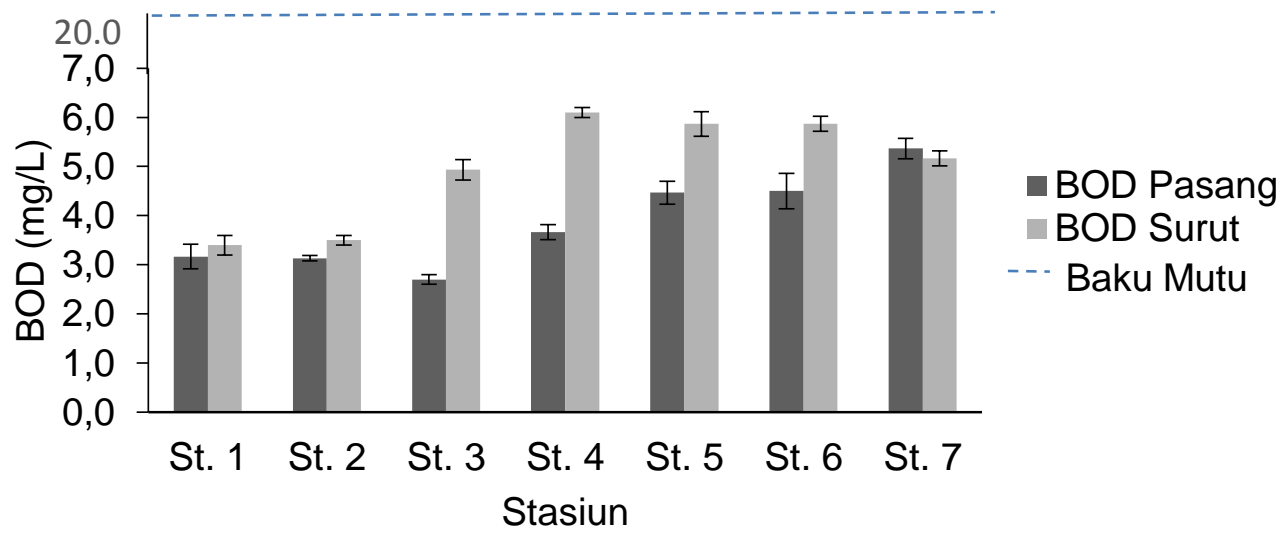

Gambar 6. Nilai rata-rata BOD di perairan Muara Sungai Jodoh, Kota Batam

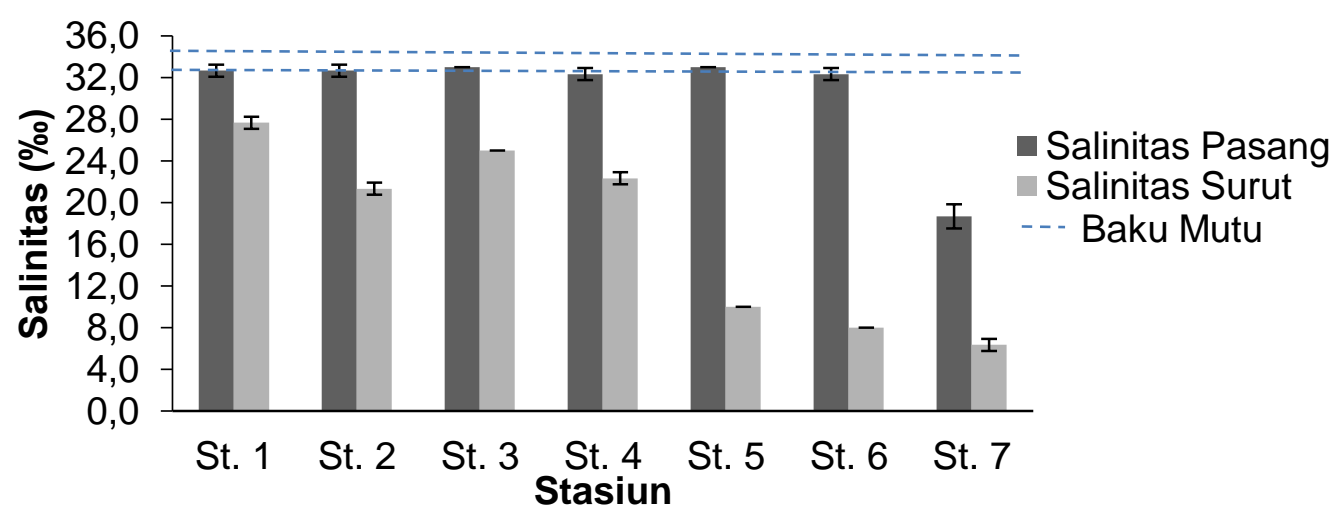

Gambar 7. Nilai rata-rata Salinitas di perairan Muara Sungai Jodoh, Kota Batam 
daratan menyebabkan nilai salinitas perairan pada saat surut berfluktuasi menurun. Menurut Arief (1984), air tawar mempunyai nilai salinitas yang rendah umumnya kurang dari 3\%, sedangkan air laut mempunyai nilai salinitas di atas 33\%. Aliran air sungai kelaut akan menimbulkan proses percampuran antara air sungai dan air laut. Dalam proses percampuran tersebut nilai salinitas akan berkisar antara nilai salinitas air tawar dan salinitas air laut.

Total Bakteri Coliform dihitung berdasarkan jumlah koloni bakteri yang tumbuh pada media uji. Menurut Widiyanti dan Ristiati (2004), Coliform merupakan suatu kelompok bakteri yang digunakan sebagai indikator adanya polusi dan kotoran yang menyebabkan kondisi air tidak baik. Hasil total Coliform pengamatan pada masing-masing stasiun penelitian disajikan pada Gambar 8.

Hasil analisis kelimpahan bakteri Coliform pada 7 stasiun pengamatan, pada saat surut kelimpahan total Coliform di stasiun 3 dan 4 didapati total coliform lebih dari 82 MPN/100 mL. Jika dilihat dari aktivitas di sekitar stasiun, stasiun 3 cukup jauh dari pemukiman yang biasanya menjadi penyumbang bakteri coliform pada perairan. Pada stasiun 6 yang merupakan pemukiman penduduk total coliform sebesar $74 \mathrm{MPN} / 100 \mathrm{~mL}$. Tingginya total coliform pada stasiun 3 diduga disebabkan oleh buangan tinja yang terbawa aliran drainase (parit) yang berada di sebelah hotel serta adanya rumah susun Lancang Kuning yang tak jauh dari wilayah tersebut.

Sedangkan pada saat pasang, jumlah koloni Coliform pada stasiun 3 menurun menjadi 38 MPN/100ml. Koloni bakteri Coliform pada saat pasang, lebih rendah disebakan oleh adanya penambahan volume air laut sehingga terjadi pengenceran air laut. Sasongko et al. (2014) menyatakan bahwa tingginya kandungan total Coliform di perairan umumnya disebabkan oleh banyaknya penduduk yang bermukim di sepanjang pantai yang masih menggunakan tinja sederhana yang langsung dibuang ke perairan laut. Hal ini diperkuat oleh Adrianto (2018), yang menyatakan bahwa limbah rumah tangga seperti feses atau sisa makanan merupakan faktor penyebab pencemaran lingkungan air oleh bakteri kelompok coliform.

Agustiningsih et al. (2012) menyatakan bahwa kelompok bakteri coliform merupakan salah satu indikator adanya kontaminan limbah domestik. Selain itu, semakin tinggi kelimpahan coliform di suatu perairan, maka semakin tinggi pula pertumbuhan bakteri patogen yang dapat mencemari biota perairan serta menyebabkan gangguan kesehatan pada manusia apabila perairan tersebut dimanfaatkan untuk kegiatan manusia (Widyaningsih, 2016). Kondisi ini diperparah dengan permukiman penduduk di atas perairan (pelantar) yang tidak dilengkapi dengan septic tank sehingga kotoran langsung dibuat keperairan.

Penentuan status mutu air pada perairan Muara Sungai Jodoh Kota Batam didasarkan atas metode Indeks Pencemaran. Suatu perairan dikatakan tercemar apabila tidak dapat digunakan sesuai dengan peruntukannya sebagaimana mestinya. Damaianto dan Masduqi (2014) menyatakan bahwa untuk melestarikan fungsi air perlu dilakukan pengelolaan kualitas dan pengendalian pencemaran air laut untuk kepentingan sekarang dan mendatang serta keseimbangan ekologis. Untuk mewujudkan peningkatan pengelolaan kualitas air laut salah satunya diperlukan suatu pendekatan indeks pencemaran. Hasil analisis nilai indeks pencemaran masing-masing stasiun pada penelitian ini disajikan pada Gambar 9.

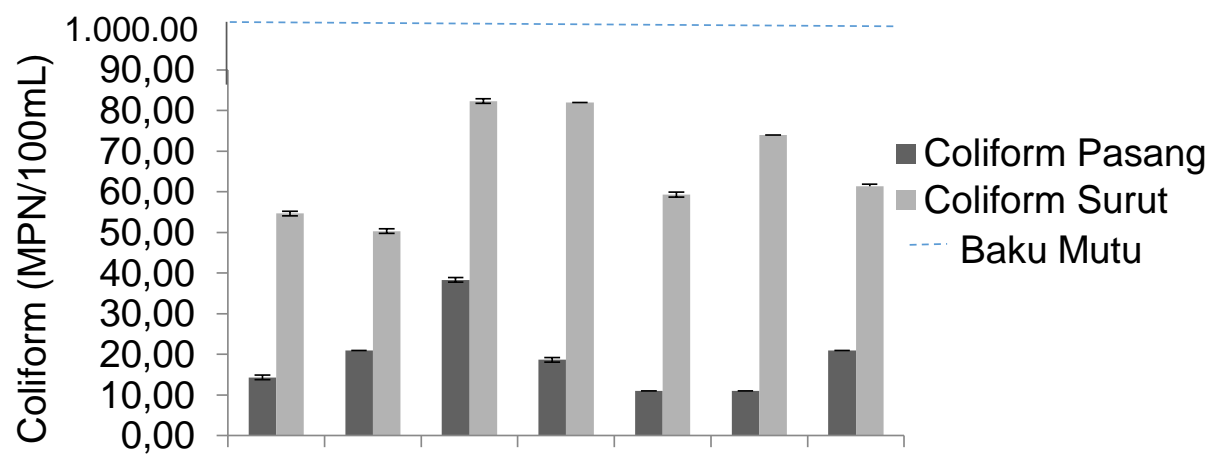

St. 1 St. 2 St. 3 St. 4 St. 5 St. 6 St. 7 Stasiun

Gambar 8. Nilai rata-rata coliform di perairan Tanjung Uma Kota Batam 


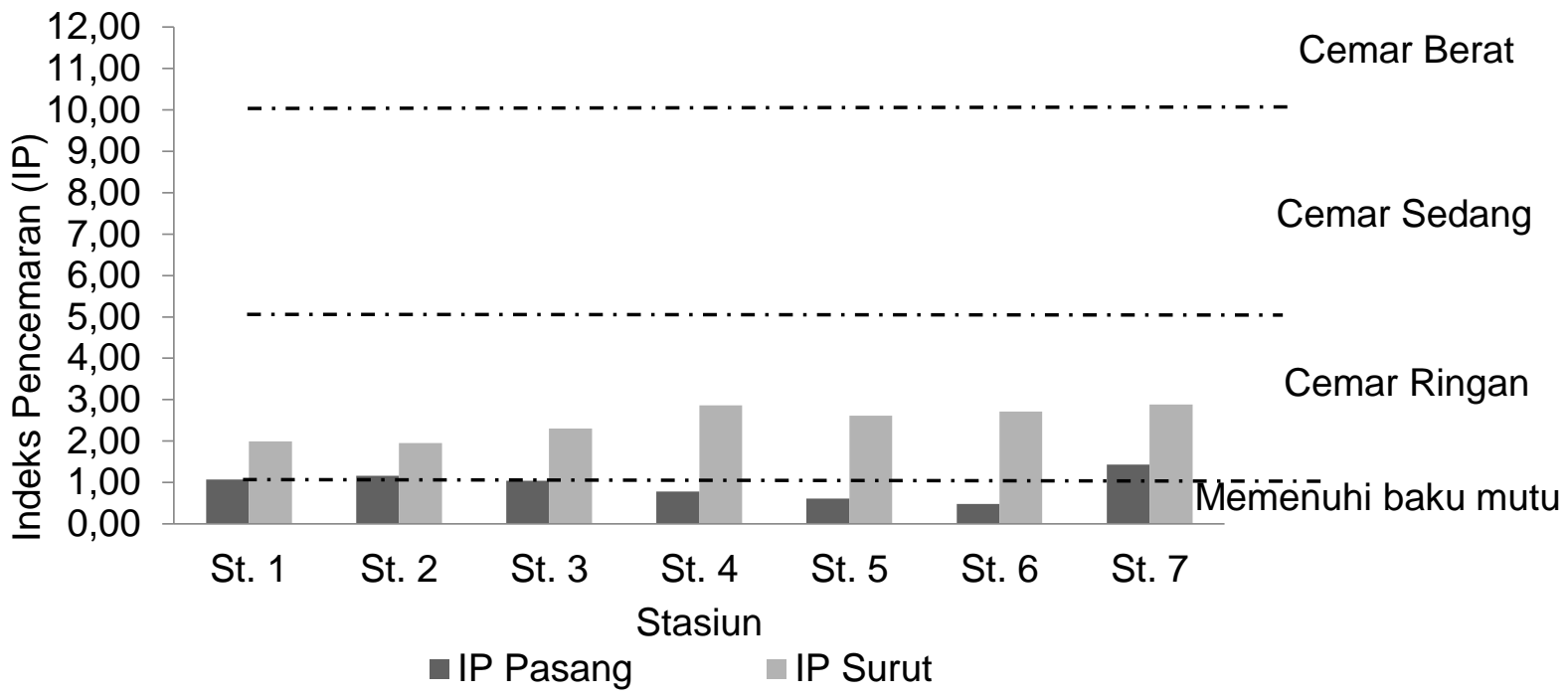

Gambar 9. Nilai rata-rata coliform di perairan Tanjung Uma Kota Batam

Berdasarkan hasil analisis Indeks Pencemaran (IP) dapat diketahui bahwa hampir seluruh stasiun pengamatan pada saat pasang masih sesuai dengan baku mutu, kecuali pada stasiun 7 yang termasuk dalam kategori tercemar ringan. Hal ini dapat disebabkan oleh beban pencemar yang diterima pada stasiun tersebut cukup tinggi. Wilayah muara sungai merupakan tempat akumulasi bahan buangan dari darat maupun laut. Hal ini ditunjukkan dengan konsentrasi parameter $\mathrm{pH}$ dan $\mathrm{BOD}$ yang menurun pada stasiun yang letaknya jauh dari muara Sungai Jodoh serta konsentrasi DO pada stasiun ini paling rendah jika dibandingkan dengan stasiun lainnya.

Sedangkan pada saat surut seluruh stasiun pengamatan tergolong dalam kategori tercemar ringan. Terjadi peningkatan nilai indeks pencemaran perairan pada saat surut, karena volume air laut mengalami penyusutan sehingga aliran drainase perkotaan yang terpengaruh oleh beragam aktivitas menyebabkan pencemaran perairan semakin meningkat.

Pada stasiun 1 dan 2 yang merupakan kawasan pasca reklamasi dan pelabuhan ferry Harbour Bay diperolah nilai indeks pencemaran sebesar 2,0. Didapati nilai $\mathrm{Ci} / \mathrm{Lij}$ baru parameter TSS 1,51 (st1) dan 1,57 (st2) dan Ci/Lij baru parameter suhu sebesar 2,71 (st1) dan 2,61 (st2). Nilai tersebut berarti perairan pada stasiun 1 dan stasiun 2 tergolong tercemar ringan. Hal ini disebabkan oleh hasil perhitungan parameter TSS dan Suhu pada stasiun tersebut tidak sesuai dengan baku mutu. Peningkatan nilai TSS di perairan menyebabkan terhalangnya penetrasi cahaya ke badan perairan sehingga organisme sulit melakukan fotosintesis yang berakibat pada menurunnya nilai DO. Disamping itu pula peningkatan suhu juga dapat menyebabkan turunnya nilai DO karena peningkatan suhu menyebabkan peningkatan konsumsi oksigen. Seperti pernyataan Effendi (2003) yang mengatakan peningkatan suhu perairan sebesar $10^{\circ} \mathrm{C}$ menyebabkan terjadinya konsumsi oksigen namun oksigen terlarut cenderung menurun akibat kenaikan suhu tersebut.

Sedangkan pada stasiun 3 yang berada disekitar restoran seafood Harbour bay diperoleh nilai indeks pencemaran sebesar 2,3. Artinya perairan tersebut tergolong tercemar ringan. Pada stasiun tersebut diperoleh nilai $\mathrm{Ci} / \mathrm{Lij}$ baru parameter Suhu sebesar 3,07 dan $\mathrm{Ci} / \mathrm{Lij}$ baru parameter $\mathrm{pH}$ sebesar 1,99.

Pada stasiun 4 didapati peningkatan nilai indeks pencemaran menjadi 2,87 selisih 0,02 dari nilai indeks pencemaran yang didapat pada stasiun 7 yaitu sebesar 2,89 . Nilai indeks pencemaran tersebut tergolong tercemar ringan. Didapati nilai $\mathrm{Ci} / \mathrm{Lij}$ baru parameter suhu dan $\mathrm{pH}>1$ yaitu sebesar 3,88 (suhu st4) dan 1,70 (pH st4) sedangkan pada stasiun 7 nilai $\mathrm{Ci} / \mathrm{Lij}$ baru sebesar 3,92 (suhu st7) dan 1,96 (pH st7). Kedua parameter tersebut tidak sesuai baku mutu. Peningkatan nilai $\mathrm{pH}$ dapat disebabkan oleh banyaknya masukan limbah yang diterima pada kedua stasiun ini. Seperti penelitian yang dilakukan oleh Sudirman dan Husrin (2014) didapati nilai pH sebesar 8,52 pada wilayah Samadikun yang merupakan wilayah pesisir Cirebon, ia menyebutkan nilai pH diatas 8,5 dikarenakan pada wilayah tersebut merupakan kawasan padat penduduk dan terdapat buangan limbah yang cukup banyak. 
Pada stasiun 5 dan 6 terjadi peningkatan konsentrasi BOD dan TSS, namun terdapat juga peningkatan konsentrasi DO yang disebabkan padatnya aktivitas pemukiman penduduk dan pelabuhan bongkar muat disekitar perairan ini. Nilai IP meningkat kembali pada stasiun 4 dimana parameter bakteri Coliform meningkat pada stasiun yang berdekatan dengan hotel serta daerah ini merupakan perairan teluk yang dialiri air laut yang berasal dari permukiman penduduk.

\section{KESIMPULAN}

Kualitas perairan pada tiap-tiap stasiun pada umumnya masih memenuhi kriteria baku mutu. Akan tetapi, pada stasiun 1 dan 2 baik saat pasang maupun surut parameter TSS tidak sesuai baku mutu. Sedangkan stasiun 3, 4, 5, 6, dan 7 pada saat surut parameter $\mathrm{pH}$ tidak sesuai dengan baku mutu. Tingkat pencemaran di perairan Muara Sungai Jodoh Kelurahan Tanjung Uma Kota Batam berdasarkan nilai indeks pencemaran pada stasiun 1,2, dan 7 pada saat pasang tergolong cemar ringan. Sedangkan disaat surut, seluruh stasiun pengamatan sudah dalam kondisi tercemar ringan.

\section{DAFTAR PUSTAKA}

Agustiningsih, D., Sasongko, S.B., \& Sudarno. 2012. Analisis Kualitas Air dan Strategi Pengendalian Pencemaran Air Sungai Blukar Kabupaten Kendal. Presipitasi, 9(2):65-71.

Ali, A., Soemarno. \& Purnomo, M. 2013. Kajian Kualitas Air dan Status Mutu Air Sungai Metro di Kecamatan Sukun Kota Malang. Bumi Lestari, 13(2):265-274.

Arief, D. 1984. Pengukuran Salinitas Air Laut dan Peranannya dalam IImu Kelautan. Oseana, $9(1): 3-10$.

BPS Kota Batam. 2018. Kota Batam Dalam Angka 2018. Badan Pusat Statistik Kota Batam. Batam.

Damaianto, B. \& Masduqi, A. 2014. Indeks Pencemaran Air Laut Pantai Utara Kabupaten Tuban dengan Parameter Logam. Teknik Promits, 3(1):1-4.

Effendi, H. 2003. Telaah Kualitas Air Bagi Pengelolaan Sumber Daya dan Lingkungan Perairan. Kanisius. Yogyakarta.

Fransisca, A. 2011. Tingkat Pencemaran Perairan Ditinjau dari Pemanfaatan Ruang di Wilayah Pesisir Kota Cilegon. Perencanaan Wilayah dan Kota. 22(2) : 145-160.

Jumali., Nurul, F., Okky, R., Nina, F.A. \& Sudarmiati. 2017. Peran Pemerintah Daerah dalam Mengoptimalisasi Penanganan Pencemaran Lingkungan di Wilayah Pesisir Kota Batam. Jurnal Selat, 5(1):25-35.

Keputusan Menteri Lingkungan Hidup Nomor 51 Tahun 2004 tentang Baku Mutu Air Laut Untuk Biota.

Keputusan Menteri Lingkungan Hidup Nomor 115 Tahun 2003 Tentang Pedoman Penentuan Status Mutu Air.

Li, M. 2014. Environmental Quality Assesment and Trend Analysis of Petroleum in Offshore Area Influencing by Reclamation. IERI Procedia. 8:142-148.

Nurfatimah, F.M., Afu, L.O.A. \& Pratikino, A.G. 2019. Sebaran Total Suspended Solid (TSS) Permukaan di Perairan Desa Wawatu, Kecamatan Moramo Utara Kabupaten Konawe Selatan. Jurnal Sapa Laut, 4(3):123-126.

Peng, B., Lin, C., Jin, D., Rao, H., Jiang, Y. \& Liu, Y. 2013. Modelling The Total Allowable Area of Coastal Reclamation : A Case Study of Xiamen, China. Ocean and Coastal Management. 76:38-44. doi: 10.1016/j.ocecoaman.2013.02.015

Salmin. 2005. Oksigen Terlarut (DO) dan Kebutuhan Oksigen Biologi (BOD) Sebagai Salah Satu Indikator untuk Menentukan Kualitas Perairan. Oseana, 30(3):21-26.

Saprial., Setiawan, B. \& Wijono, D. 2004. Konflik Lingkungan di Kampung Agas, Tanjung Uma, Batam. Jurnal Manusia dan Lingkungan, 11(3):112-125.

Sasongko, E.B., Widyastuti, E. \& Priyono, R.E. 2014. Kajian Kualitas Air dan Penggunaan Sumur Gali Oleh Masyarakat di Sekitar Sungai Kaliyasa Kabupaten Cilacap. Jurnal IImu Lingkungan; 12(2):72-82. doi: 10.14710/jil.12.2.72-82 
Simanjuntak, M. 2012. Kualitas Air Laut Ditinjau Dari Aspek Zat Hara, OksigenTerlarut dan pH di Perairan Banggai, Sulawesi Tenggara. Jurnal IImu dan Teknologi KelautanTropis; 4(2):290303.

Sudirman, N. \& Husrin, S. 2014. Status Baku Mutu Air Laut Untuk Kehidupan Biota dan Indeks Pencemaran Perairan Pesisir Cirebon Pada Musim Kemarau. Jurnal Ilmiah Perikanan dan Kelautan, 6(2):14-22.

Supenah, P., Widyastuti, E. \& Priyono, R.E. 2015. Kajian Kualitas Air Sungai Condong yang Terkena Buangan Limbah Cair Industri Batik Trusmi Cirebon. Biosfera. 32(2):111-118.

Triyulianti, I., Putri, M.R. \& Tito, C.K. 2012. Telaah Suhu, Salinitas, dan pH Kaitannya dengan Kondisi Tekanan Parsial Karbondioksida $\left(\mathrm{pCO}_{2}\right)$ di Perairan Muara Sungai Kapuas. Badan Penelitian dan Pengembangan Kelautan dan Perikanan. 188-197.

Widiyanti, N.L. \& Ristiati, N.P. 2004. Analisa Kualitatif Bakteri Coliform Pada Depot Air Minum Isi Ulang di Kota Singaraja Bali. Jurnal Ekologi Kesehatan, 3(1): 64-73.

Yudo, S. 2010. Kondisi kualitas air Sungai Ciliwung di Wilayah DKI Jakarta Ditinjau dari Parameter Organik, Amoniak, Fosfat, Deterjen dan Bakteri Coli. Jurnal Akuakultur Indonesia, 6(1):34-42.

Yurnita. A, Trisutomo. S, Ali. M. 2017. Model Reklamasi Pantai Secara Berkelanjutan, Kasus : Pantai Kota Makassar. Tata Loka, 19(4):339-354. doi: 10.14710/tataloka.19.4.339-354 